\title{
Short communication: Reference limits for blood analytes in Holstein late-pregnant heifers and dry cows: Effects of parity, days relative to calving, and season
}

\author{
M. Brscic, ${ }^{*}$ G. Cozzi, ${ }^{* 1}$ I. Lora, ${ }^{*}$ A. L. Stefani, $†$ B. Contiero, ${ }^{*}$ L. Ravarotto,† and F. Gottardo* \\ *Department of Animal Medicine, Production and Health, University of Padova, Viale dell'Università 16, 35020 Legnaro (PD), Italy \\ †Istituto Zooprofilattico Sperimentale delle Venezie, Viale dell'Università 10, 35020 Legnaro (PD), Italy
}

\begin{abstract}
Reference limits for metabolic profiles in Holstein late-pregnant heifers and dry cows were determined considering the effects of parity, days relative to calving, and season. Blood samples were collected from 104 pregnant heifers and 186 dry cows (68 primiparous and 118 pluriparous) from 60 to $10 \mathrm{~d}$ before the expected calving date in 31 dairy farms in northeastern Italy. Sampling was performed during summer (182 samples) and the following winter (108 samples). All the animals were judged as clinically healthy at a veterinary visit before sampling. Outliers were removed from data of each blood analyte, and variables that were not normally distributed were log transformed. A mixed model was used to test the fixed effects of parity (late-pregnant heifers, primiparous or pluriparous dry cows), class of days relative to calving (60-41 d, 40-21 d, 20-10 d), season (summer or winter), and the interactions between parity and class of days relative to calving and between parity and season, with farm as random effect. Single general reference limits and $95 \%$ confidence intervals were generated for analytes that did not vary according to fixed effects. Whenever a fixed effect included in the model significantly affected a given analyte, specific reference limits and 95\% confidence intervals were generated for each of its levels. Albumin, urea, triglycerides, alanine aminotransferase, aspartate aminotransferase, creatinine kinase, conjugated bilirubin, calcium, phosphorus, magnesium, potassium, chloride, zinc, copper, and iron concentrations were not influenced by any of the fixed effects. Total protein, globulins, creatinine, glucose, alkaline phosphatase, gamma glutamyltransferase, lactate dehydrogenase, and sodium plasma concentrations were affected by parity. The class of days relative to calv-
\end{abstract}

Received January 15, 2015.

Accepted July 15, 2015.

${ }^{1}$ Corresponding author: giulio.cozzi@unipd.it ing had a significant effect on the concentrations of total protein, globulins, fatty acids, cholesterol, total bilirubin, and sodium. Season affected plasma concentrations of creatinine, glucose, fatty acids, lactate dehydrogenase, and sodium. Interactions between parity and class of days relative to calving and between parity and season did not significantly affect any of the blood analytes tested. The reference limits and the $95 \%$ confidence intervals for blood analytes determined in the study could help dairy practitioners to improve the accuracy of metabolic profile interpretation in Holstein late-pregnant cattle.

Key words: blood reference limit, Holstein, latepregnant heifer, dry cow

\section{Short Communication}

Laboratory blood analysis is becoming an essential tool for dairy practitioners in their assessment of cow health and prevention of metabolic disease (Oetzel, 2004). It is well known that many factors such as breed, age, physiological stage, and season may affect cattle blood-analyte concentration (Shaffer et al., 1981). Therefore, each laboratory measurement should be compared with appropriate reference limits for its correct interpretation. Reference limits for lactating Holstein cows, considering the effects of parity, stage of lactation, and season were determined by Cozzi et al. (2011). Some information is available in literature on metabolic profile variations in dairy cows during the transition period (Bionaz et al., 2007; Ospina et al., 2010; Chapinal et al., 2011), and reference limits for biochemical and hematological analytes have been reported by Quiroz-Rocha et al. (2009) for dairy cows 1 wk before and 1 wk after calving. No blood reference limits for biochemical analytes in late-pregnant dairy cattle have been published yet. The present study aimed to determine reference limits and 95\% confidence intervals for blood analytes of Holstein late-pregnant 
heifers and dry cows from 60 to $10 \mathrm{~d}$ before the expected calving date by testing the effects of parity, days relative to calving, and season.

The study was carried out in a convenience sample of 31 Holstein dairy farms located in northeastern Italy. The Italian Holstein cattle population consists of more than one million cows (ANAFI, 2015). These cows have a strong genetic relation with both American and Canadian Holsteins, as shown by the genetic correlation values for milk yield $(\mathrm{r}=0.92$ and $\mathrm{r}=0.91$, respectively) reported by Interbull (2014). Farm selection criteria were the same as those used by Cozzi et al. (2011): good production performances, low incidence of nutritionally related diseases, herd size ( $>30$ lactating cows), rolling milk yield (>8,000 kg of milk), bulktank SCC $(<300,000 / \mathrm{mL})$, culling rate $(<30 \%)$, and days open $(<150)$. Additional selection criteria were the low prevalence of peripartum diseases, the use of TMR feeding system for dry cows and pregnant heifers formulated in accordance with the NRC (2001), and a location within a 2 -h drive from the laboratory. All selected farmers were willing to participate in the study, and a farm veterinarian was available to perform clinical visits and blood samplings. Late-pregnant heifers and dry cows from 60 to $10 \mathrm{~d}$ before expected calving date were included in the study. Five animals per farm were scheduled to be sampled (2 pregnant heifers and 3 dry cows, at least 1 of which was primiparous) in summer (from August to early September) and in the following winter (from January to early March). According to ASVCP (2011), all animals reported by the stockman to show signs of illness within 2 wk before the day of blood sampling were excluded a priori. The study considered only clinically healthy animals based on a veterinary visit performed $24 \mathrm{~h}$ before blood sampling. Consistent with Cozzi et al. (2011), the clinical examination considered body temperature (acceptable interval from 38.0 to $\left.39.0^{\circ} \mathrm{C}\right)$; rumination activity $(\geq 60$ chews per cud); urine analysis by Combur-Test strips (Roche Diagnostics S.p.A., Milan, Italy), pH (accepted interval: 8.2 to 8.4 ), ketones (absence), and proteins (absence); and fecal score from 2 to 3 according to the method proposed by Hutjens (2002). A BCS between 3.0 and 3.5 (Edmonson et al., 1989) was a further inclusion criteria. Individual blood samples were always collected in the morning before TMR distribution from the jugular vein into vacuum tubes containing 150 US Pharmacopeia units of lithium heparin (Vacutainer; Becton, Dickinson and Co., Franklin Lakes, NJ) and were kept at $4^{\circ} \mathrm{C}$ until laboratory processing. All samples were centrifuged at $1.500 \times g$ for $15 \mathrm{~min}$ at $4^{\circ} \mathrm{C}$ within $2 \mathrm{~h}$, and plasma was then stored at $-18^{\circ} \mathrm{C}$. Of the total 305 blood samples taken, 15 were discarded due to hemolysis, and 290 samples were used in the study: 104 from late-pregnant heifers and 186 from dry cows (68 primiparous and 118 pluriparous). A total of 182 samples were collected during summer and 108 during winter.

Plasma samples were analyzed for biochemical analytes of protein traits and energy metabolism markers (total protein, albumin, globulins, urea, creatinine, glucose, triglycerides, fatty acids), enzymes and hepatic markers [alanine aminotransferase, aspartate aminotransferase, alkaline phosphatase (ALP), gamma glutamyltransferase (GGT), lactate dehydrogenase (LDH), creatinine kinase, cholesterol, and conjugated and total bilirubin], and minerals (calcium, phosphorus, magnesium, sodium, potassium, chloride, zinc, copper, and iron). Samples were tested with a Hitachi 911 (F. Hoffmann-La Roche Ltd., Basel, Switzerland) at $37^{\circ} \mathrm{C}$. Plasma fatty acids concentration was measured with an enzymatic colorimetric method (Randox Laboratories Ltd., Crumlin, UK), whereas Roche BM commercial kits were used for the other determinations. Analytical methods used for each blood analyte and the corresponding laboratory assay quality were reported by Cozzi et al. (2011).

Statistical analysis of blood analytes was performed using SAS 9.2 software (SAS Institute Inc., Cary, NC). Outlier data with more than 3 standard deviations from the mean were removed from the data set, and the number of samples for each blood analyte is reported in Table 1. Normal distribution of all variables was checked using PROC UNIVARIATE, and coefficients of skewness and kurtosis were calculated to determine distribution asymmetry and peakedness. Variables with Shapiro-Wilk values $<0.98$ were log transformed for normalization before statistical analysis. Independent variables (main factors) were parity (late-pregnant heifers, primiparous or pluriparous dry cows), class of days relative to calving (60-41 d, 40-21 d, 20-10 d), and season (summer or winter). Mean values were calculated for each blood analyte within farm for the 3 main factors with a farm-level approach to decrease variability (Cozzi et al., 2011). All variables were statistically analyzed using PROC MIXED by a linear model that considered parity, class of days relative to calving, season, interaction between parity and class of days relative to calving, and interaction between parity and season as fixed effects, and the random effect of the farm.

Post hoc multiple comparisons between least squares means were performed by Bonferroni adjustment option. Reference limits and 95\% confidence intervals were generated according to ASVCP (2011) using a parametric method based on the distribution of the reference values. Whenever a fixed effect of the model significantly affected $(P<0.001)$ a given analyte, spe- 
cific reference limits and $95 \%$ confidence intervals were generated for each of its levels. Single general reference limits and 95\% confidence intervals were determined for the remaining analytes. Results for log-transformed variables were reported after back transformation.

The outcomes of statistical analysis showed that the random effect of the farm explained less than $30 \%$ of the variability for all dependent variables except for urea $(36.0 \%)$, glucose $(34.8 \%)$, and alanine aminotransferase $(36.9 \%)$. The fixed effects of the interactions between parity and class of days relative to calving, and between parity and season, did not significantly affect $(P>0.001)$ any of the blood-analyte concentrations. Albumin, urea, triglycerides, alanine aminotransferase, aspartate aminotransferase, creatinine kinase, conjugated bilirubin, $\mathrm{Ca}, \mathrm{P}, \mathrm{Mg}, \mathrm{K}, \mathrm{Cl}, \mathrm{Zn}, \mathrm{Cu}$, and $\mathrm{Fe}$ concentrations were not affected $(P>0.001)$ by any of the main factors tested, and their means, general reference limits, and general $95 \%$ confidence intervals are reported in Table 2 .

Total protein and globulins concentrations varied by parity $(P<0.001$; Table 3$)$ and class of days relative to calving $(P<0.001$; Table 4$)$. Comparisons of parity levels showed increasing concentrations of total protein with increasing parity of the animals $(P<0.05)$, in line with previous studies (Russell and Roussel, 2007; Kaneko et al., 2008; Quiroz-Rocha et al., 2009). Globulin concentrations were higher in primiparous and pluriparous dry cows than in heifers $(P<0.05)$, and this is likely due to the better immunological memory of older animals, as suggested by Devery-Pocius and Larson (1983). Total protein and globulins concentrations were the lowest in the closest class of days (20-10 d) relative to calving $(P<0.05)$. Considering that albumin concentration was not affected by days relative to calving, it could be assumed that the variation observed for total protein concentration was due to the variation of globulins concentration. Concentrations of the different fractions of globulins may be reduced in cows and heifers in the 20- to 10-d time interval because they are entering the transition period, which is characterized by a certain energy deficit that could lead to a reduction in hepatic synthesis and by some degree of nonspecific immunosuppression that leads to a decline in both neutrophil and lymphocyte functions (Goff, 2008).

Table 1. Number of blood samples (after outlier deletion) and mean, median, minimum, maximum, inferior and superior quartiles, W value of Shapiro-Wilk normality test, and SD of the measured blood analytes of Holstein late-pregnant heifers and dry cows

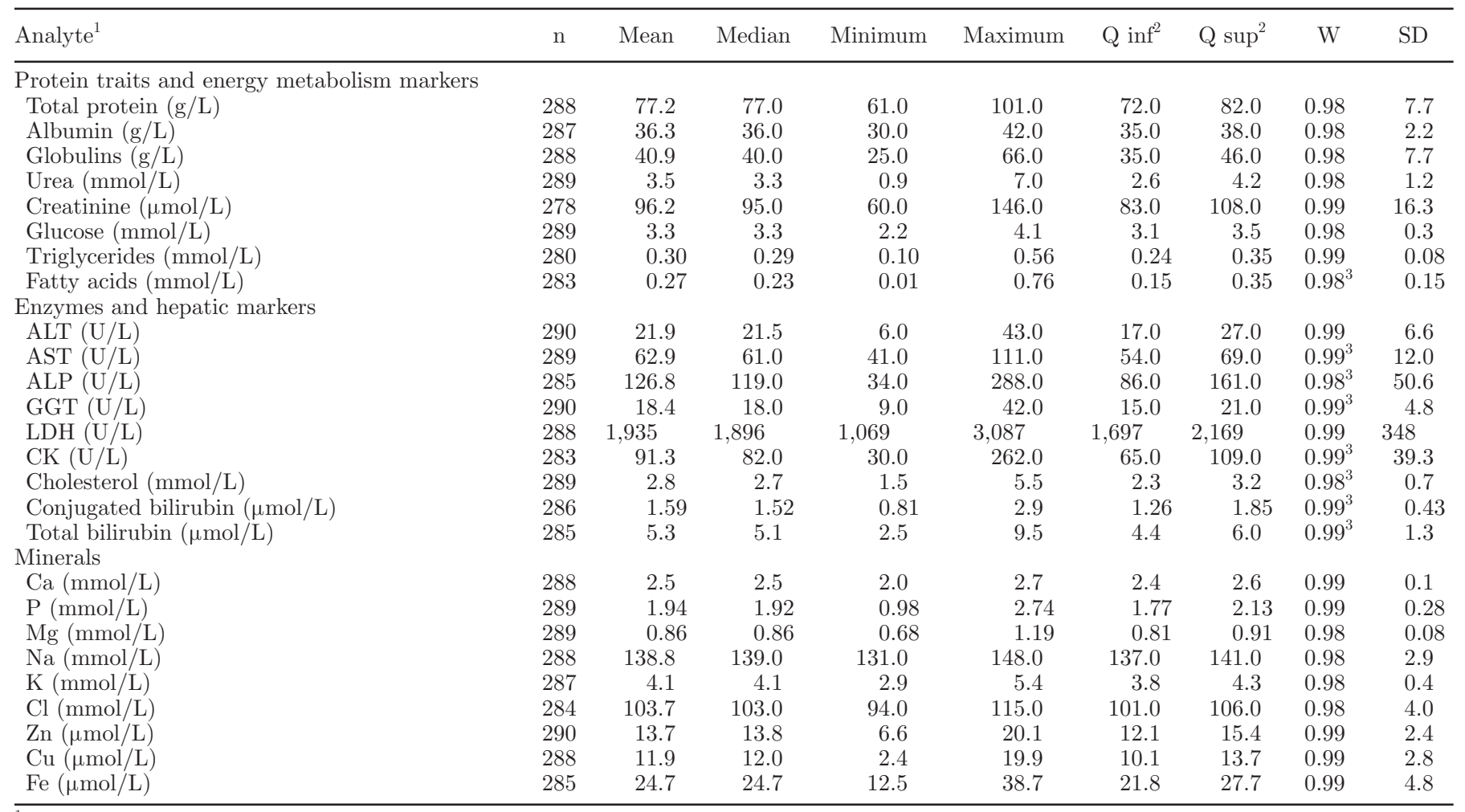

${ }^{1} \mathrm{ALT}=$ alanine aminotransferase; AST $=$ aspartate aminotransferase; ALP $=$ alkaline phosphatase; GGT = gamma glutamyltransferase; LDH $=$ lactate dehydrogenase; $\mathrm{CK}=$ creatinine kinase.

${ }^{2} \mathrm{Q}$ inf = inferior quartile; $\mathrm{Q}$ sup = superior quartile.

${ }^{3}$ Value obtained after logarithmic transformation of the analyte. 
Creatinine and glucose concentrations varied by parity $(P<0.001)$ with the same trend (Table 3$)$. The higher creatinine concentration observed for latepregnant heifers compared with both primiparous and pluriparous dry cows $(P<0.05)$ could be due to the higher relative muscular mass of heifers, considering that almost all creatinine is released by striated muscle, and its plasma concentration is reported to be an index of muscle mass (Doornenbal et al., 1988; Russell and Roussel, 2007). Other explanations related to higher muscle activity in young growing cattle cannot be excluded, however. As suggested by Shaffer et al. (1981), it could be hypothesized that the higher glucose concentration in pregnant heifers than primiparous and pluriparous dry cows $(P<0.05)$ was related to declining metabolic rates and glucose activity at increasing age. The higher metabolic rate in younger animals is linked to the growth process, which requires moderate quantities of energy, in fact. Creatinine and glucose concentrations varied also by season $(P<0.001)$ but with opposite trends (Table 5). The coping of animals with hot environmental conditions could be a plausible explanation for the higher creatinine and the lower glucose concentrations observed in summer. In response to high temperatures, cattle have a greater energy expense for thermoregulation and a parallel reduction of DMI (Wheelock et al., 2010), which may lead to reduced glucose availability and consequent muscle protein catabolism (Abeni et al., 2007). As expected from previous literature (LeBlanc, 2010), fatty acids concentration was affected by class of days relative to calving $(P<$ 0.001; Table 4) with an increasing trend among time intervals and reached the highest concentration in the class that was 20 to $10 \mathrm{~d}$ relative to calving. In late pregnancy, cattle undergo several hormonal changes (particularly a decrease in insulin concentration and an increase in somatotropin) and a reduction in DMI that leads to lipid mobilization from adipocytes, resulting in a higher plasma fatty acids concentration (Ospina et al., 2010; Chapinal et al., 2011). A similar hypothesis related to a more severe drop of DMI in late-pregnant cattle exposed to a hot environment could be a plausible explanation for the higher concentration of fatty acids $(P<0.001)$ in summer than winter (Table 5$)$.

Alkaline phosphatase, GGT, and LDH activities varied among parity levels $(P<0.001$; Table 3$)$. Decreasing ALP activities were observed at increasing parity $(P<0.05)$. According to Fernandez and Kidney (2007), nonhepatic increases in ALP activity were found in young animals because of physiological changes. Therefore, the higher ALP activities observed in this study for younger cattle may arise from the increased osteoblastic activity due to skeletal growth, as suggested by van Mosel and Corlett (1990), Allen (2003), and Russell and Roussel (2007). The higher GGT activity of primiparous and pluriparous dry cows compared with heifers $(P<0.05)$ might be a long-term effect of the hepatic stress induced by the preceding lactation

Table 2. Mean, reference limits, and 95\% CI of the blood analytes of Holstein late-pregnant heifers and dry cows that were not affected $(P>0.001)$ by parity, class of days relative to calving, or season or by the interactions between parity and class of days relative to calving and between parity and season

\begin{tabular}{|c|c|c|c|c|c|}
\hline \multirow[b]{2}{*}{ Analyte $^{1}$} & \multirow[b]{2}{*}{$\mathrm{n}$} & \multirow[b]{2}{*}{ Mean } & \multicolumn{2}{|c|}{ Reference limit ${ }^{2}$} & \multirow[b]{2}{*}{$95 \% \mathrm{CI}$} \\
\hline & & & Low & High & \\
\hline \multicolumn{6}{|c|}{ Protein traits and energy metabolism markers } \\
\hline Albumin $(\mathrm{g} / \mathrm{L})$ & 287 & 36.3 & 32.1 & 40.6 & $36.1-36.6$ \\
\hline Urea $(\mathrm{mmol} / \mathrm{L})$ & 289 & 3.5 & 1.1 & 5.8 & $3.3-3.6$ \\
\hline Triglycerides $(\mathrm{mmol} / \mathrm{L})$ & 280 & 0.30 & 0.14 & 0.46 & $0.29-0.31$ \\
\hline \multicolumn{6}{|l|}{ Enzymes and hepatic markers } \\
\hline ALT (U/L) & 290 & 21.9 & 9.0 & 34.9 & $21.2-22.7$ \\
\hline $\operatorname{AST}^{3}(\mathrm{U} / \mathrm{L})$ & 289 & 61.9 & 43.3 & 88.5 & $60.6-63.2$ \\
\hline $\mathrm{CK}^{3}(\mathrm{U} / \mathrm{L})$ & 283 & 84.4 & 39.4 & 180.6 & $80.6-88.3$ \\
\hline Conjugated bilirubin ${ }^{3}(\mu \mathrm{mol} / \mathrm{L})$ & 286 & 1.53 & 0.92 & 2.6 & $1.5-1.6$ \\
\hline \multicolumn{6}{|l|}{ Minerals } \\
\hline $\mathrm{Ca}(\mathrm{mmol} / \mathrm{L})$ & 288 & 2.5 & 2.2 & 2.7 & $2.4-2.5$ \\
\hline $\mathrm{P}(\mathrm{mmol} / \mathrm{L})$ & 289 & 1.9 & 1.4 & 2.5 & $1.9-2.0$ \\
\hline $\mathrm{Mg}(\mathrm{mmol} / \mathrm{L})$ & 289 & 0.86 & 0.71 & 1.02 & $0.85-0.87$ \\
\hline $\mathrm{K}(\mathrm{mmol} / \mathrm{L})$ & 287 & 4.1 & 3.3 & 4.9 & $4.1-4.2$ \\
\hline $\mathrm{Cl}(\mathrm{mmol} / \mathrm{L})$ & 284 & 103.7 & 95.9 & 111.6 & $103.2-104.2$ \\
\hline $\mathrm{Zn}(\mu \mathrm{mol} / \mathrm{L})$ & 290 & 13.7 & 8.9 & 18.4 & $13.4-14.0$ \\
\hline $\mathrm{Cu}(\mu \mathrm{mol} / \mathrm{L})$ & 288 & 11.9 & 6.4 & 17.4 & $11.6-12.3$ \\
\hline $\mathrm{Fe}(\mu \mathrm{mol} / \mathrm{L})$ & 285 & 24.7 & 15.3 & 34.1 & $24.1-25.2$ \\
\hline
\end{tabular}




\begin{tabular}{|c|c|c|c|c|c|c|c|c|c|c|c|c|c|c|c|}
\hline \multirow[b]{3}{*}{ Analyte $^{1}$} & \multicolumn{5}{|c|}{ Heifer } & \multicolumn{5}{|c|}{ Primiparous dry cow } & \multicolumn{5}{|c|}{ Pluriparous dry cow } \\
\hline & \multirow[b]{2}{*}{$\mathrm{n}$} & \multirow[b]{2}{*}{ Mean } & \multicolumn{2}{|c|}{ Reference limit ${ }^{2}$} & \multirow[b]{2}{*}{$95 \% \mathrm{CI}$} & \multirow[b]{2}{*}{$\mathrm{n}$} & \multirow[b]{2}{*}{ Mean } & \multicolumn{2}{|c|}{ Reference limit ${ }^{2}$} & \multirow[b]{2}{*}{$95 \%$ CI } & \multirow[b]{2}{*}{$\mathrm{n}$} & \multirow[b]{2}{*}{ Mean } & \multicolumn{2}{|c|}{ Reference limit ${ }^{2}$} & \multirow[b]{2}{*}{$95 \%$ CI } \\
\hline & & & Low & High & & & & Low & High & & & & Low & High & \\
\hline \multicolumn{16}{|c|}{ Protein traits and energy metabolism markers } \\
\hline Total protein $(\mathrm{g} / \mathrm{L})$ & 103 & $72.7^{\mathrm{c}}$ & 60.4 & 85.1 & $71.5-74.0$ & 68 & $77.1^{\mathrm{b}}$ & 64.2 & 90.0 & $75.5-78.7$ & 117 & $81.3^{\mathrm{a}}$ & 67.1 & 95.4 & $79.9-82.6$ \\
\hline Globulins $(\mathrm{g} / \mathrm{L})$ & 103 & $36.8^{\mathrm{b}}$ & 24.6 & 49.1 & $35.6-38.1$ & 68 & $40.9^{\mathrm{a}}$ & 26.9 & 54.9 & $39.2-42.7$ & 117 & $44.3^{\mathrm{a}}$ & 29.4 & 59.2 & $42.9-45.7$ \\
\hline Creatinine $(\mu \mathrm{mol} / \mathrm{L})$ & 103 & $102.9^{\mathrm{a}}$ & 70.4 & 135.5 & $99.7-106.2$ & 63 & $92.1^{\mathrm{b}}$ & 62.8 & 121.3 & $88.3-95.8$ & 112 & $92.4^{\mathrm{b}}$ & 63.3 & 121.4 & $89.6-95.1$ \\
\hline Glucose $(\mathrm{mmol} / \mathrm{L})$ & 103 & $3.4^{\mathrm{a}}$ & 2.8 & 4.0 & $3.3-3.5$ & 68 & $3.2^{\mathrm{b}}$ & 2.5 & 3.8 & $3.1-3.3$ & 118 & $3.2^{\mathrm{b}}$ & 2.6 & 3.8 & $3.1-3.2$ \\
\hline \multicolumn{16}{|c|}{ Enzymes and hepatic markers } \\
\hline $\mathrm{ALP}^{3}(\mathrm{U} / \mathrm{L})$ & 104 & $156.8^{\mathrm{a}}$ & 85.0 & 289.3 & $147.5-166.6$ & 64 & $116.2^{\mathrm{b}}$ & 61.4 & 220.0 & 107.1-126.1 & 117 & $90.3^{\mathrm{c}}$ & 45.4 & 179.6 & $84.7-96.3$ \\
\hline $\mathrm{GGT}^{3}(\mathrm{U} / \mathrm{L})$ & 104 & $15.5^{\mathrm{b}}$ & 10.3 & 23.2 & $14.8-16.1$ & 68 & $18.6^{\mathrm{a}}$ & 12.6 & 27.3 & $17.7-19.5$ & 118 & $19.7^{\mathrm{a}}$ & 12.2 & 31.7 & $18.9-20.6$ \\
\hline $\mathrm{LDH}(\mathrm{U} / \mathrm{L})$ & 102 & $2,089^{\mathrm{a}}$ & 1,399 & 2,778 & $2,019-2,158$ & 68 & $1,904^{\mathrm{b}}$ & 1,324 & 2,483 & $1,832-1,975$ & 118 & $1,821^{\mathrm{c}}$ & 1,183 & 2,460 & $1,762-1,881$ \\
\hline \multicolumn{16}{|l|}{ Minerals } \\
\hline $\mathrm{Na}(\mathrm{mmol} / \mathrm{L})$ & 102 & $139.6^{\mathrm{a}}$ & 134.3 & 145.0 & $139.1-140.2$ & 68 & $138.2^{\mathrm{b}}$ & 132.7 & 143.7 & $137.5-138.9$ & 118 & $138.3^{\mathrm{b}}$ & 132.6 & 144.1 & $137.8-138.9$ \\
\hline
\end{tabular}

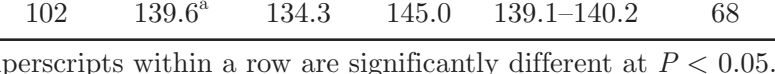

${ }^{a-c}$ Values with different superscripts within a row are significantly different at $P<0.05$.

${ }^{2}$ Parametric method applied when data were normally distributed (ASVCP, 2011).

${ }^{3}$ Analyte reported after antilog transformation.

Table 4. Mean, reference limits, and $95 \%$ CI of the blood analytes of Holstein late-pregnant heifers and dry cows that were affected by the class of days relative to calving $(P<$ $0.001)$

Class of days relative to calving

\begin{tabular}{|c|c|c|c|c|c|c|c|c|c|c|c|c|c|c|c|}
\hline \multirow[b]{3}{*}{ Analyte } & \multicolumn{5}{|c|}{$60-41 \mathrm{~d}$} & \multicolumn{5}{|c|}{$40-21 \mathrm{~d}$} & \multicolumn{5}{|c|}{$20-10 \mathrm{~d}$} \\
\hline & \multirow[b]{2}{*}{$\mathrm{n}$} & \multirow[b]{2}{*}{ Mean } & \multicolumn{2}{|c|}{ Reference limit $^{1}$} & \multirow[b]{2}{*}{$95 \% \mathrm{CI}$} & \multirow[b]{2}{*}{$\mathrm{n}$} & \multirow[b]{2}{*}{ Mean } & \multicolumn{2}{|c|}{ Reference limit $^{1}$} & \multirow[b]{2}{*}{$95 \%$ CI } & \multirow[b]{2}{*}{$\mathrm{n}$} & \multirow[b]{2}{*}{ Mean } & \multicolumn{2}{|c|}{ Reference limit ${ }^{1}$} & \multirow[b]{2}{*}{$95 \%$ CI } \\
\hline & & & Low & High & & & & Low & High & & & & Low & High & \\
\hline \multicolumn{16}{|c|}{ Protein traits and energy metabolism markers } \\
\hline Total protein $(\mathrm{g} / \mathrm{L})$ & 81 & $77.7^{\mathrm{a}}$ & 63.2 & 92.3 & $76.1-79.4$ & 128 & $78.4^{\mathrm{a}}$ & 62.7 & 94.0 & $77.0-79.8$ & 79 & $74.8^{\mathrm{b}}$ & 61.0 & 88.7 & $73.3-76.4$ \\
\hline Globulins $(\mathrm{g} / \mathrm{L})$ & 81 & $41.1^{\mathrm{a}}$ & 26.4 & 55.9 & $39.5-42.8$ & 127 & $42.0^{\mathrm{a}}$ & 26.6 & 57.4 & $40.6-43.4$ & 80 & $38.7^{\mathrm{b}}$ & 24.3 & 53.1 & $37.1-40.4$ \\
\hline Fatty $\operatorname{acids}^{2}(\mathrm{mmol} / \mathrm{L})$ & 81 & $0.18^{\mathrm{c}}$ & 0.06 & 0.57 & $0.16-0.21$ & 128 & $0.23^{\mathrm{b}}$ & 0.07 & 0.75 & $0.21-0.26$ & 74 & $0.29^{\mathrm{a}}$ & 0.10 & 0.86 & $0.26-0.33$ \\
\hline \multicolumn{16}{|c|}{ Enzymes and hepatic markers } \\
\hline Cholesterol $^{2}(\mathrm{mmol} / \mathrm{L})$ & 81 & $3.0^{\mathrm{a}}$ & 1.8 & 4.9 & $2.8-3.2$ & 128 & $2.7^{\mathrm{b}}$ & 1.7 & 4.4 & $2.6-2.9$ & 80 & $2.5^{\mathrm{c}}$ & 1.6 & 3.8 & $2.4-2.6$ \\
\hline Total bilirubin $^{2}(\mu \mathrm{mol} / \mathrm{L})$ & 81 & $4.7^{\mathrm{b}}$ & 2.8 & 7.7 & $4.4-5.0$ & 127 & $5.1^{\mathrm{a}}$ & 3.2 & 8.1 & $4.9-5.3$ & 77 & $5.6^{\mathrm{a}}$ & 3.5 & 9.1 & $5.3-5.9$ \\
\hline \multicolumn{16}{|c|}{ Minerals } \\
\hline $\mathrm{Na}(\mathrm{mmol} / \mathrm{L})$ & 79 & $138.0^{\mathrm{b}}$ & 133.0 & 143.0 & $137.4-138.6$ & 129 & $138.5^{\mathrm{b}}$ & 133.3 & 143.8 & $138.1-139.0$ & 80 & $139.9^{\mathrm{a}}$ & 133.5 & 146.2 & $139.2-140.6$ \\
\hline
\end{tabular}

${ }^{\mathrm{a}-\mathrm{c}}$ Values with different superscripts within a row are significantly different at $P<0.05$.

${ }^{1}$ Parametric method applied when data were normally distributed (ASVCP, 2011).

${ }^{2}$ Analyte reported after antilog transformation. 


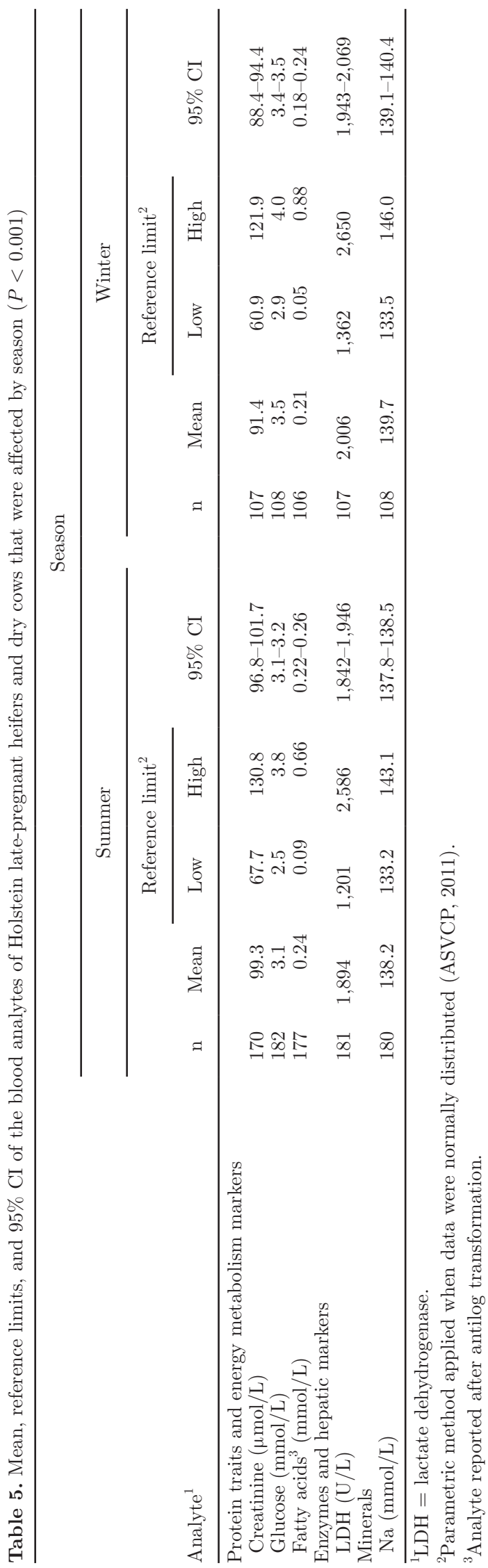

because GGT is considered a specific hepatic marker in cattle and its plasma activity tends to increase in cases of chronic liver disorders (Stojević et al., 2005; Russell and Roussel, 2007). Variation of LDH activities at the 3 parity levels was similar to that of creatinine but differed from that of GGT. Therefore, the increasing LDH activities observed in younger animals $(P<$ $0.05)$ can be primarily ascribed to the contribution of the muscular fraction rather than the hepatic fraction of the enzyme. Indeed, after sexual maturity, muscle metabolism in growing cattle gradually shifts from glycolytic (higher LDH activity) to more oxidative (lower LDH activity) (Hocquette et al., 1998). Activity of LDH was affected also by season $(P<0.001$; Table $5)$, with lower values recorded during summer. This result is not consistent with other literature reports. Abeni et al. (2007) found no variation in LDH activity even in heat-stressed dairy cows. Cholesterol and total bilirubin concentrations varied by class of days relative to calving $(P<0.001$; Table 4$)$. In accordance with findings by Bionaz et al. (2007) and Bossaert et al. (2012), cholesterol concentration decreased among time intervals, with the lowest value in the class that was 20 to $10 \mathrm{~d}$ relative to calving. Cholesterol plasma concentration depends mainly on blood lipoproteins of hepatic and intestinal origin; therefore, its value could be physiologically lowered in late-pregnant cattle experiencing a DMI reduction (Bertoni and Trevisi, 2013). Total bilirubin concentration was higher $(P<0.05)$ in the 2 classes of days relative to calving closer to parturition (40-21 d and 20-10 d) than in the farthest one (60-41 d). This might be a physiological variation in cattle approaching the transition period, and it is likely linked to a reduced synthesis of the hepatic enzymes responsible for bilirubin clearance as a consequence of a grade of subclinical inflammatory condition that often occurs in cows before calving (Bionaz et al., 2007; Bertoni and Trevisi, 2013).

Among minerals, only Na concentration was affected by parity $(P<0.001$; Table 3$)$, class of days relative to calving $(P<0.001$; Table 4$)$, and season $(P<0.001$; Table 5). Sodium concentration was higher in heifers than in primiparous and pluriparous dry cows $(P<$ $0.05)$, and it was higher in the class that was 20 to $10 \mathrm{~d}$ relative to calving than in the farther ones $(P<$ 0.05). These trends observed have no clear biological explanation, however, and are not supported by updated literature. The lower $\mathrm{Na}$ concentration observed in summer than in winter was in some way expected, considering the mineral losses due to sweating. No further significant seasonal variations existed for the other sweat mineral constituents measured, however.

Investigation of blood analytes during late pregnancy could be an effective practice in dairy cattle health 
monitoring aimed at preventing peripartum disorders. To this end, the specific reference limits and $95 \%$ confidence intervals for metabolic profiles reported in the current study after taking the effects of parity, days relative to calving, and season into account could offer dairy practitioners a useful tool that improves the accuracy of blood analysis interpretation in Holstein cattle.

\section{ACKNOWLEDGMENTS}

This study was supported by a grant of the University of Padova within the EX $60 \%$ research funds.

\section{REFERENCES}

Abeni, F., L. Calamari, and L. Stefanini. 2007. Metabolic conditions of lactating Friesian cows during the hot season in the Po valley. 1. Blood indicators of heat stress. Int. J. Biometeorol. 52:87-96. http://dx.doi.org/10.1007/s00484-007-0098-3.

Allen, M. J. 2003. Biochemical markers of bone metabolism in animals: Uses and limitations. Vet. Clin. Pathol. 32:101-113. http:// dx.doi.org/10.1111/j.1939-165X.2003.tb00323.x.

ANAFI (Associazione Nazionale Allevatori Frisona Italiana). 2015 Average Milk/Fat/Protein Yield Milk Recorded Holstein-Friesian Cows 2013. Accessed Jan. 15, 2015. http://www.anafi.it/english/.

ASVCP (American Society for Veterinary Clinical Pathology). 2011. ASVCP Reference Interval Guideline. Guidelines for the determination of reference intervals (RI) in veterinary species. Accessed Jan. 14, 2014. http://www.asvcp.org/pubs/qas/index.cfm.

Bertoni, G., and E. Trevisi. 2013. Use of the liver activity index and other metabolic variables in the assessment of metabolic health in dairy herds. Vet. Clin. North Am. Food Anim. Pract. 29:413-431.

Bionaz, M., E. Trevisi, L. Calamari, F. Librandi, A. Ferrari, and G. Bertoni. 2007. Plasma paraoxonase, health, inflammatory conditions, and liver function in transition dairy cows. J. Dairy Sci. 90:1740-1750. http://dx.doi.org/10.3168/jds.2006-445.

Bossaert, P., E. Trevisi, G. Opsomer, G. Bertoni, S. De Vliegher, and J. L. M. R. Leroy. 2012. The association between indicators of inflammation and liver variables during the transition period in high-yielding dairy cows: An observational study. Vet. J. 192:222225. http://dx.doi.org/10.1016/j.tvjl.2011.06.004.

Chapinal, N., M. Carson, T. F. Duffield, M. Capel, S. Godden, M. Overton, J. E. P. Santos, and S. J. LeBlanc. 2011. The association of serum metabolites with clinical disease during the transition period. J. Dairy Sci. 94:4897-4903. http://dx.doi.org/10.3168/ jds.2010-4075.

Cozzi, G., L. Ravarotto, F. Gottardo, A. L. Stefani, B. Contiero, L. Moro, M. Brscic, and P. Dalvit. 2011. Short communication: reference values for blood parameters in Holstein dairy cows: Effects of parity, stage of lactation, and season of production. J. Dairy Sci. 94:3895-3901. http://dx.doi.org/10.3168/jds.2010-3687.

Devery-Pocius, J. E., and B. L. Larson. 1983. Age and previous lactations as factors in the amount of bovine colostral immunoglobulins. J. Dairy Sci. 66:221-226. http://dx.doi.org/10.3168/jds. S0022-0302(83)81780-9.
Doornenbal, H., A. K. W. Tong, and N. L. Murray. 1988. Reference values of blood parameters in beef cattle of different ages and stages of lactation. Can. J. Vet. Res. 52:99-105.

Edmonson, A. J., I. J. Lean, L. D. Weaver, T. Farver, and G. Webster 1989. A body condition scoring chart for Holstein dairy cows. J. Dairy Sci. 72:68-78.

Fernandez, N. J., and B. A. Kidney. 2007. Alkaline phosphatase: Beyond the liver. Vet. Clin. Pathol. 36:223-233

Goff, J. P. 2008. Transition cow immune function and interaction with metabolic diseases. Pages $45-57$ in Proc. 17th Annu. Tri-State Dairy Nutr. Conf. The Ohio State University, Columbus.

Hocquette, J. F., I. Ortigues-Marty, D. Pethick, P. Herpin, and X. Fernandez. 1998. Nutritional and hormonal regulation of energy metabolism in skeletal muscles of meat-producing animals. Livest. Prod. Sci. 56:115-143. http://dx.doi.org/10.1016/S03016226(98)00187-0.

Hutjens, M. F. 2002. A blueprint for evaluating feeding programs. Adv. Dairy Technol. 14:147-159.

Interbull. 2014. Interbull routine genetic evaluation for dairy production traits. Accessed Jan. 14, 2015. http://www.interbull.org/web/ static/mace_evaluations_archive/eval/prod-apr14.html.

Kaneko, J. J., J. W. Harvey, and M. L. Bruss. 2008. Clinical Biochemistry of Domestic Animals. 6th ed. Acad. Press, Burlington, MA.

LeBlanc, S. 2010. Monitoring metabolic health of dairy cattle in the transition period. J. Reprod. Dev. 56:S29-S35. http://dx.doi. org/10.1262/jrd.1056S29.

NRC. 2001. Nutrient Requirements of Dairy Cattle. 7th rev. ed. Natl Acad. Sci, Washington, DC.

Oetzel, G. R. 2004. Monitoring and testing dairy herds for metabolic disease. Vet. Clin. North Am. Food Anim. Pract. 20:651-674 http://dx.doi.org/10.1016/j.cvfa.2004.06.006.

Ospina, P. A., D. V. Nydam, T. Stokol, and T. R. Overton. 2010. Evaluation of nonesterified fatty acids and beta-hydroxybutyrate in transition dairy cattle in the northeastern United States: Critical thresholds for prediction of clinical diseases. J. Dairy Sci. 93:546-554. http://dx.doi.org/10.3168/jds.2009-2277.

Quiroz-Rocha, G. F., S. J. LeBlanc, T. F. Duffield, D. Wood, K. E. Leslie, and R. M. Jacobs. 2009. Reference limits for biochemical and hematological analytes of dairy cows one week before and one week after parturition. Can. Vet. J. 50:383-388.

Russell, K. E., and A. J. Roussel. 2007. Evaluation of the ruminant serum chemistry profile. Vet. Clin. North Am. Food Anim. Pract. 23:403-426. http://dx.doi.org/10.1016/j.cvfa.2007.07.003.

Shaffer, L., J. D. Roussel, and K. L. Koonce. 1981. Effects of age, temperature-season, and breed on blood characteristics of dairy cattle. J. Dairy Sci. 64:62-70. http://dx.doi.org/10.3168/jds. S0022-0302(81)82529-5.

Stojević, Z., J. Piršljin, S. Milinković-Tur, M. Zdelar-Tuk, and B. B. Ljubić. 2005. Activities of AST, ALT and GGT in clinically healthy dairy cows during lactation and in the dry period. Veterinarski Arhiv. 75:67-73.

van Mosel, M., and S. C. Corlett. 1990. Assessment of bone turnover in the dry period of dairy cows by measurement of plasma bone GLA protein, total plasma alkaline phosphatase activity and urinary hydroxyproline. Exp. Physiol. 75:827-837.

Wheelock, J. B., R. P. Rhoads, M. J. Vanbaale, S. R. Sanders, and L. H. Baumgard. 2010. Effects of heat stress on energetic metabolism in lactating Holstein cows. J. Dairy Sci. 93:644-655. http://dx.doi. org/10.3168/jds.2009-2295. 